\title{
POLLY HILL: CROSSING AND CONTESTING THE BOUNDARIES OF ANTHROPOLOGY, ECONOMICS, AFRICAN STUDIES, AND ENTREPRENEURSHIP STUDIES
}

\author{
BY ROBERT DIMAND* AND KOJO SAFFU**
}

\begin{abstract}
Polly Hill spent her long, productive and at times controversial career crossing and contesting disciplinary boundaries. She graduated in economics at Cambridge, but her doctorate was in social anthropology - with economist Joan Robinson as dissertation supervisor. Her thirteen years at the University of Ghana were initially in Economics, then in African Studies, and her readership at Cambridge was in Commonwealth Studies. As a woman in several male-dominated academic disciplines without a secure base in any (and with distinctive, unorthodox opinions in each), she never obtained a tenure-track appointment despite ten books and fifty scholarly articles. Her books drew attention to the underrecognized agency of indigenous entrepreneurs while her Development Economics on Trial: The Anthropological Case for the Prosecution (1986) critiqued a discipline, of disciplinary boundaries, and of outside experts, both mainstream and radical.

* Department of Economics, Brock University, rdimand@brocku.ca

** Goodman School of Business, Brock University ksaffu@brocku.ca
\end{abstract}

This "preprint" is the peer-reviewed and accepted typescript of an article that is forthcoming in revised form, after minor editorial changes, in the Journal of the History of Economic Thought (ISSN: 1053-8372), issue TBA. Copyright to the journal's articles is held by the History of Economics Society (HES), whose exclusive licensee and publisher for the journal is Cambridge University Press (https://www.cambridge.org/core/journals/journal-of-the-history-of-economic-thought ). This preprint may be used only for private research and study and is not to be distributed further.

The preprint may be cited as follows:

Dimand, Robert and Kojo Saffu. Polly Hill: Crossing and Contesting the Boundaries of Anthropology, Economics, African Studies, and Entrepreneurship Studies. Journal of the History of Economic Thought (forthcoming). Preprint at SocArXiv, osf.io/preprints/socarxiv 


\section{Polly Hill: Crossing and Contesting the Boundaries of Anthropology, Economics, African Studies, and Entrepreneurship Studies ${ }^{1}$}

\section{INTRODUCTION}

"As an economist concerned with African primary producers, I have found it necessary to trespass in the fields of history, geography, sociology and anthropology, particularly the latter" (PH/Box24/Folder 4).

The British scholar Polly Hill spent her long, productive and at times contentious career crossing and contesting disciplinary boundaries, making major contributions relevant to development economics and development studies, social and economic anthropology, African studies and Commonwealth studies, women's studies and entrepreneurship. Her books on The Gold Coast Cocoa Farmer (1956), The Migrant Cocoa-Farmers of Southern Ghana: A Study in Rural Capitalism (1963), and Studies in Rural Capitalism in West Africa (1970) stressed the underrecognized agency of indigenous entrepreneurs, especially female entrepreneurs.

Nonetheless, as a woman crossing the boundaries of several male-dominated ${ }^{2}$ disciplines without a secure base in any of them and with distinctive, unorthodox opinions to express in each (e.g., criticizing neoclassical and Marxist advice to developing countries), she never obtained a tenuretrack or equivalent appointment despite publishing ten books and fifty scholarly articles (and despite noteworthy family connections) and is little noticed in the collective memory of several relevant disciplines. Her Development Economics on Trial: The Anthropological Case for the Prosecution (1986) was a searing critique of a discipline, of disciplinary boundaries, and of the pretensions of outside experts, both mainstream and radical - an insightful contribution but, like

\footnotetext{
${ }^{1}$ We are very grateful to Gerardo Serra for sharing his transcripts from the Polly Hill Papers.

${ }^{2}$ Women's studies did not yet exist as a field in which academic employment was available. See Claire Robertson (1984) for later work in the field directly relevant to Hill's research.
} 
her other writings, notendearing its author to the powers-that-be in any discipline or political camp. Even her last and most prestigious academic appointment, as Smuts Reader in Commonwealth Studies at Cambridge University, was for a fixed term and paid only $£ 1,000$ a year.

We use archival materials, Polly Hill's writings and her career to show her disciplinary identities and the intersection points between disciplines. We inquire why despite Polly Hill's productive scholarship she never obtained a secure academic position. Was it the case of a woman crossing the boundaries of male-dominated academic disciplines or was it something else? We contrast her career with two British contemporaries, Peter Bauer, her predecessor as Smuts Reader at Cambridge and like Hill a researcher who emphasized rationality and market forces in West African trade (Bauer 1948), and T. Scarlett Epstein who, like Hill, followed a first degree in economics (with, like Hill, a grade of 2.1) with a doctorate in anthropology but, unlike Hill, came to be accepted in her new discipline. Polly Hill's crossing of disciplinary boundaries is reflected in co-authorship of this paper by a historian of economics whose thesis brought him to the 1983 Keynes centenary conference at King's College, which Polly Hill attended as John Maynard Keynes's niece and as editor of Lydia Lopokova's letters to Keynes before their marriage, and an entrepreneurship professor whose mother and uncle were Ghanaian cocoa farmers studied by Polly Hill and whose father was a cocoa buyer.

\section{A PRODUCTIVE CAREER WITHOUT A DISCIPLINARY HOME}

Mary Eglantyne Hill (always known as Polly) was born in 1914, the eldest child of A. V. Hill, a Nobel Prize-winning physiologist who was also, in World War I, a pioneer of operational research (see A. V. Hill 1960, pp. 265-67, 306-10), and Margaret Neville Hill, née Keynes, a 
social worker and Royal Commission member. Polly Hill studied economics at Newnham College, Cambridge, receiving "the title of the Degree of Bachelor of Arts" (but, as a woman before 1948, not full membership of the university) in 1936 with a 2.1 (Second Class Honours, Upper Division, incurring her father's great displeasure), just missing the First usually required for a college fellowship or postgraduate study. She assisted her uncle John Maynard Keynes in his editing of the Economic Journal and wrote a Fabian Society report on the

Unemployment Services (Hill 1940). She was a civil servant in London from 1940 to 1951, at the Treasury, Board of Trade, and Statistics Division of the Colonial Office. In 1940-41 she lived at 46 Gordon Square, home of Maynard Keynes and Lydia Lopokova, whose letters she later edited with her cousin Richard Keynes, and was dining with Keynes when a bomb exploded opposite the house.

Polly Hill left the Colonial Office in 1951 to go to the Gold Coast (independent as Ghana from 1957) as commercial editor of West Africa, a weekly magazine (biographical information in this paper is drawn from Macfarlane 1996, Austin 1997, Hart 2005, Gregory 2006, and Dimand and Saffu 2017). From 1953, she was married for eight years, but published under her maiden name. From 1954 to 1964 she was a Research Fellow (later Senior Research Fellow) at the University College of the Gold Coast (which became the University of Ghana), with a research grant from the West African Institute of Social and Economic Research to study cocoa farmers. Initially in the Department of Economics, the first economics department in sub-Saharan Africa outside South Africa. There she published a book with Oxford University Press (The Gold Coast Cocoa Farmer, 1956) and, from 1957 to 1960, a Cocoa Research Series of nineteen reports published by the Economics Department (PH, Box 6, Folders 1 through 6). She combined statistical surveys with ethnographic methods in a manner unusual for economists: "Should not 
the field-economist strive to be an anthropologist with an extensive approach? Is not the humility which the economist faced with unfamiliar tropical conditions is wont to feel in relation to the anthropologist, a reflection of the inappropriateness of his technique? The experiment, the results of which are related in these pages, was undertaken in the belief that the field-economist (given as he must be to the collection of figures) has something to contribute" (1956, p. 2). But despite this indication of her future research path, Hill later partially repudiated her 1956 preliminary survey as "a pathetic little book" (interview with Macfarlane 1996) when she discovered that many of the farmers who had made southern Ghana the world's leading cocoa producer and exporter were migrant entrepreneurs from northern Ghana. This discovery led to Migrant Cocoa Farmers of Southern Ghana (Hill 1963), deservedly reprinted more than three decades later as a "Classic in African Anthropology" (see Austin 1997), and to Studies in Rural Capitalism in West Africa (1970).

Hill spent 1960-61 on leave as a Smuts Visiting Fellow at Cambridge's Department of Social Anthropology, invited by Professor Meyer Fortes. Fortes had studied the Asante (Ashanti), the ethnicity of Hill's migrant cocoa farmers, and could empathize with scholars crossing between disciplines: his firstdoctorate was in psychology and he had been a psychologist at an East London child guidance clinic for several years before studying anthropology under Bronislaw Malinowski at LSE (Kuper 1973, p. 91). Returning, and finding herself out of sympathy with an increasingly left-wing, statist Economics Department (whose changing disposition paralleled the increasing socialist militancy of President Nkrumah's regime), Hill applied for and received a transfer in 1963 to the interdisciplinary Institute for African Studies. She returned to England in 1964 when she felt that her daughter was at risk from malaria, and became a non-stipendiary research fellow at Clare Hall, Cambridge. "Non- 
stipendiary" meant unpaid, so she had to support herself, her daughter and her research from small external research grants and from family sources, as was also largely the case during her Smuts Readership from 1973. In 1967 Polly Hill received a PhD in social anthropology from the University of Cambridge, with her already-published Migrant Cocoa Farmers (1963) accepted as the dissertation, and with the radical Cambridge economist Joan Robinson as dissertation supervisor, rather than an anthropologist such as Meyer Fortes (who had written the foreword to Hill 1963). Fortes and Robinson, who both died in 1983, posthumously shared the dedication of Hill (1986) as "my two great teachers in the two disciplines."

While an unpaid research fellow at Clare Hall, Hill conducted field work in northern Nigeria leading to Rural Hausa: A Village and a Setting (1972), followed, while she was Smuts Reader, by Population, Prosperity, and Poverty: Rural Kano, 1900 and 1970 (1977), extending her approach to historical comparison across time. After her readership expired in 1979, she remained a productive scholar without academic affiliation, stipend or office space. Further field work on southern India led to a cross- continent comparison, Dry Grain Farming Families: Hausaland (Nigeria) and Karnataka (India) Compared (1982) ${ }^{3}$. Critical reflection on disciplines within and across which she had worked led to Development Economics on Trial: The Anthropological Case for a Prosecution (1986), while Fante Villages in Southern Ghana (1992) returned to study of migration and farming in southern Ghana. She edited the letters of her aunt,

\footnotetext{
${ }^{3}$ At Clare Hall, Hill was a colleague of another Joan Robinson protégé with an interest in Indian farming, Krishna Bharadwaj. Although primarily an economic theorist in the tradition of Piero Sraffa (see the essays collected in Bharadwaj 1989), Bharadwaj (1974) wrote a Department of Applied Economics monograph on Indian agriculture that according to Harcourt (1993-94, p. 305) "was in fact completed in 1968", that is, while she was at Clare Hall from 1967 until she returned to India in 1971. Harcourt (1993-94, p. 305) observed that "The liberation of her thinking from the restriction of the demand and supply equilibrium framework allowed [Bharadwaj 1974] to combine historical, institutional, and sociological insights with her earlier expertise on production interdependence and the nature of production processes."
} 
the Russian ballerina Lydia Lopokova, to Maynard Keynes before their marriage, while her cousin Richard Keynes edited Maynard's letters to Lydia (Hill and Keynes, eds., 1989). Her history of the people of the Fens in Cambridgeshire was privately published in 1990, but her last book, on the history of women at Cambridge, was never published.

\section{POLLY HILL'S DISCIPLINARY IDENTITIES}

Carried down-stream by a fast-flowing river to the further (anthropological) bank

Polly Hill graduated in economics from Cambridge and worked as an economist in the Civil Service. However, venturing into the forests of southern Ghana to study cocoa farmers in the field, she quickly realized that she needed to forge a new path and appropriate research methodologies with their associated data collection techniques combining ethnographic methods and statistics. Experiencing practice in the field, she was at variance with economic orthodoxy, whether neoclassical or Marxist. The dialectic tension and conflict called for inventiveness and passion.

In November 1960, while a visiting fellow in anthropology at Cambridge, Hill wrote to Joan Robinson that "For a long time I have now tried to sit in the middle of the fast-flowing river between economics and anthropology, but naturally I have been carried down-stream and thrown onto the further (anthropological) bank" (PH Box 20, Folder 2, quoted by Serra 2018, p. 97). Hill used terms such as "field economics" (Hill 1956) or "indigenous economics" (Hill 1966) to describe her approach. As she made the transition from identifying as an economist to seeking a doctorate in anthropology, Hill followed advice from Meyer Fortes to adopt the already-existing term economic anthropologist, rather than her preferred choice "anthropological economist" (Hill to Raymond Firth 31/10/65, PH Box 20, Folder 6). 
Fortes (foreword to Hill 1963, p. v) wrote that "Miss Hill calls herself a 'field economist' to distinguish her methods from those of the more normal variety of economist who nowadays swoops down upon an 'underdeveloped country' for a week or a month, peruses the files and the blue books, and presently produces a plan or a treatise.” Writing to economic anthropologist Harold Schneider (02/11/1964, PH 20/5), Hill included Schneider and University of Chicago development economist (and future Nobel laureate) Theodore Schultz in a small "imagined community" of "true" field economists, although, as Schneider wrote to her (27/10/64, PH20/5), authentic field or indigenous economists following "correct" observational practice were so scarce as to be "a voice in the wilderness" (Serra 2018, p. 99). Hill (1970, p. 15) insisted that non-indigenous economists "are apt to be so much less sophisticated than their subjects, the farmers" and that "the Marxist textbooks are no more relevant than the capitalist variety."

Thomas Hodgkin of the Institute of African Studies (IAS), writing to the university's vice-chancellor to approve Hill's request to transfer from Economics to IAS, wrote that "she is convinced that she has ceased to be an economist and has become what might be described as an African economist and social historian with strong sociological interests that her interests and future career therefore necessarily lie in the field of African studies." Hill saw her books as "providing a service not only for scholars within and without Ghana, but also for the general reader whose interest has been captivated by the rapidly developing field of African Studies" (PH Box 24, Folder 1). Hill (1972, p. 5) described her book Rural Hausa as an effort to use detailed study of socio-economic life in a single northern Nigerian village, particularly economic inequality, to formulate hypotheses testable elsewhere in Hausaland but as "also an attempt to demonstrate that when studying the structure of socio-economic life in a small West African rural community, there are places and circumstances in which an approach based on 
isolating economic factors within a sociological framework may be even more illuminating than one of wider more sociological scope."

She consistently opposed persistent misconceptions such as belief in the rudimentary nature of rural economic systems, lacking foresight or the incentive to work hard, or the economists' folklore that farmers planted just enough to see them through harvest after harvest. Hill (1972, p. 6) singled out for criticism views on northern Nigeria's economy of Dame Margery Perham $(1937,1946,1960)$, once her senior colleague in the Colonial Office, quoting claims by Perham (1960, p. 41) that northern Nigerian farmers lacked the foresight or incentive "to work more than the low standards of well-being demand" and that "There was only a rudimentary monetary and exchange system and the ruling class, or men of exceptional enterprise, could hardly obtain the laborers their activities required except by compulsion."

Hill felt that some African economists adopted mistaken beliefs of outside experts: "Convinced as they have been of the simplicity of indigenous economic organization, few of them [visiting economic advisers], or, indeed, of the growing band of prominent West African economists (most of the Nigerians), have used their influence to urge the need for more 'grass roots research"” (Hill 1970, p. 9), a remark in a chapter (“A Plea for Indigenous Economics”) first presented at a conference in Nigeria. Hill (1970, p. 9) was no more tactful when decrying W. Arthur Lewis's "much-read" 1953 report on industrialization in the Gold Coast for "an oversimplified image of agricultural organization based on the presumption that a simple technology necessarily implies simple socio-economic organization, 'inefficiency' (in some absolute, though undefined, sense), and small-scale production - though none of these notions is necessarily true or meaningful." Following up on Hill (1970), chapters in Hill (1986) denounced "The Vain Search for Universal Generalizations" and "The Poor Quality of Official Statistics." Hill's 
critique of official statistics in Africa was been taken up by Morten Jerven (2013, 2015), with minimal mention of Hill (Jerven 2013, pp. 77-78, cites Hill 1986 on inappropriate statistical categories used by the UN Food and Agriculture Organization).

\section{THE TROUBLED RELATIONS BETWEEN ECONOMICS AND ANTHROPOLOGY}

"By default, social science research in a colonial context was linked to social anthropology, a nascent discipline" according to Keith Tribe (2018, p. 102). According to Jack Goody (1995), social anthropology predated development economics as a recognized academic subdiscipline. George Dalton (1968, p. 180) described economics and anthropology as, among all the social sciences, "least alike in their traditions, methods, contents" - a contrast that Dalton, the editor of Karl Polanyi's selected essays, was well placed to observe, holding a professorship in both economics and anthropology at Northwestern University.

Four decades earlier, economic historian N. S. B. Gras, writing on "Anthropology and Economics" in The Social Sciences and their Interrelations, observed that "Economics and anthropology have grown up largely independent of one another" and that while economic history and social psychology had resulted from interaction between disciplines "There is no such union of economics and anthropology" (Ogburn and Goldenweiser, eds., 1927, p. 10). The emergence and nature of economic anthropology has started to receive some attention in the history of economics (Lodewijks 1994, Scott and Young 2016) and of anthropology (Hann and Hart 2016) but makes little appearance in more general histories of those disciplines (e.g. Kuper 1973, Goody 1995).

The University of Chicago economists Frank Knight (1941) and Richard Posner (1980) wrote review articles on anthropological works on the economic life of traditional societies, 
urging anthropologists to consider observed behavior as the outcome of constrained optimization by rational individuals, with, in Posner's case, emphasis on the economic theory of information and decision-making under risk. Some anthropologists took note, with Melville Herskovits reprinting Knight's critique of his book in the revised edition (see Scott and Young 2016). Formalists in the formalist/substantivist debate within anthropology in the 1950s and 1960s argued for the applicability of neoclassical economic theory (Firth, ed., 1967,

Hopkins 1973, p. 6, Hill 1986, p. 22n). Knight and Posner viewed communication between economists and anthropologists as unidirectional, with anthropologists learning to think like economists. Polly Hill (1986, pp. 21-24) remarked that, while it was commendable of neoclassical economists Christopher Bliss (noted for work in capital theory) and Nicholas Stern (later Lord Stern, of the Stern Report on global climate change) to spend considerable time in situ studying the Indian village of Palanpur, they didn't consult any anthropological work on south Indian agriculture or villagers. Bliss and Stern (1982, p. 4) undertook their project holding that "the theories of development economics should have the power to explain what one finds in a village such as Palanpur" but concluded, in puzzlement, that "We are unable to confirm that neo-classical economics is alive and well and residing in Palanpur, at least in its simplest forms" (1982, p. 291). Development economist Pranab Bardhan later helped institute more balanced conversations between economists and anthropologists, first among those studying rural India (Bardhan, ed., 1989) and then more generally (Bardhan and Ray, eds., 2008).

While criticizing the neoclassical formalism of Bliss and Stern, Hill was no more sympathetic to the substantivist alternative of Karl Polanyi's followers represented by Bohannan and Dalton (1962), which underemphasized the economic importance of trade in African market places. According to Hill (1986, p. 55n), "The useful, though over-influential Markets in Africa 
(1962) is flawed by the unrealistic introduction by the two substantivist editors, Bohannan and Dalton, the one an anthropologist, the other an economist [so much for Dalton's crossappointment!]; so far as West (but not East) Africa was concerned, they showed a lack of timedepth in associating the growth of market places with colonialism (which in northern Nigeria, for instance, was a period of little more than half a century, ending in 1960) and they were wrong in asserting that 'the more pervasive the market principle, the less the economic importance of the market place' (p. 25). (Fortunately, nearly all economists ignored their views; this was not surprising considering that market place is seldom an entry in the indexes of contemporary economic textbooks.)"

This criticism of "lack of time-depth" was also reflected in Hill's dismissal of Cambridge economics professor Nicholas Kaldor (on the opposite side of the Cambridge capital controversies from Bliss), who came as Nkrumah's tax advisor in 1961 without knowledge of the Ghanaian context and history: "There are the forward-looking politicians and the crazy economic policologists (a word I did not coin myself) like Kaldor [...] whose very purpose is to look back as little as possible, so as to be free to move forward" (PH Box 20, Folder 4, quoted by Serra 2018, p. 98).

Hill (1979) also sharply criticized a work that could not be accused of "a lack of timedepth" about West African economies: A. G. Hopkins's Economic History of West Africa (1973). The correspondence surrounding the exchange between Hill (1979) and Hopkins (1979) in African Economic History was quite heated; the title that she gave to Box 18, Folder 1, of the Polly Hill Papers is "Hopkins/AEH (African Economic History Journal) Ordeal” (cf. Austin 2011).

Polly Hill's work on grass-roots rural capitalism differed greatly from the advocacy of 
socialist planning in Robinson (1979), yet Robinson provided Hill with a sympathetic ear and academic support at Cambridge. Also starting with a 2.1 in Economics at Cambridge, Joan Robinson overcame obstacles due to gender, politics, and personal differences to succeed as a Cambridge economist, being promoted from assistant lecturer to lecturer five years after her book on imperfect competition (and after two books on Keynesian macroeconomics) and in 1949 to Reader, and finally receiving a professorship after three decades of teaching (Aslanbeigui and Oakes 2009, Kerr 2017). She made her way in a male-dominated discipline at a university that had only recently admitted women to degrees, and presumably she recognized similar determination and strength of conviction in Hill.

Polly Hill's complex and varying disciplinary identities stemmed from her divergence from theories accepted as orthodox in economics, whether neoclassical or Marxian, or in anthropology. Her consternation with the dialectic tension between the disciplines emanated from her long stay studying Ghanaian cocoa farmers. This led her to forge her distinctive methodological approach incorporating varied observational types, surveys, statistics, ethnographic methods, interviews, anecdotes, stories or narratives.

While economics focused on how economic phenomena were identified and observed, anthropology entailed observing individuals at work through ethnographic study, participant observation, intensive data collection at the micro level (Serra 2018). Polly Hill focused on local activities and institutions that comprised or encapsulated economic life in rural Ghana (Hill 1956, 1963, 1970, 1992) and Hausaland (Hill 1972, 1977, 1982). She was a bridge builder between the two disciplines. Hill's methods amount to what Gerardo Serra (2018) calls seeking parts looking for wholes. Polly Hill shifted the observational focus from economic agents such as cocoa farmers and individual industries (cocoa farming) to a single rural village in Northern 
Nigeria to get "a total picture of poverty" by directing the lens or attention on rich and poor farmers.

\section{ENTREPRENEURSHIP}

Polly Hill advanced understanding of indigenous entrepreneurship through her use of unique qualitative lens on indigenous economies and systems, a neglected subject that, as Hill (1986, p. 70) remarked, was of little interest to mainstream economists when Hill (1956, 1963, 1970) published, but has since attracted more attention (e.g. Ruth Simms 1981 and Saffu and Anum 2005 on African women entrepreneurs), more from growth of entrepreneurship studies in business schools than from a change of attitude among mainstream economists.

Polly Hill drew attention to "those enterprising and wily migrant cocoa farmers of southern Ghana" (1986, p.12), "capitalists" who without any assistance whatsoever from the government ${ }^{4}$ singlehandedly created a cocoa industry in southern Ghana from the ground up, attaining an enviable spot on the global stage, as the largest cocoa producer in the world by 1945 and for fifteen years thereafter, until the export taxes and marketing monopoly of the Nkrumah government undermined incentives to produce and export cocoa. The migrant cocoa farmers were entrepreneurs par excellence, in the true sense of Joseph Schumpeter ([1911] 1934) because, while cocoa had been introduced from Fernando Po to the Gold Coast in $1876^{5}$, cocoa

\footnotetext{
${ }^{4}$ As Hart $(2005$, p. 31) remarked in his obituary of Hill, "She was able to show that the cocoa farmers were an authentic modern class, migrant entrepreneurs opening up virgin forest often in companies capable of hiring Swiss construction firms to develop the infrastructure that they needed and that the colonial authorities could not provide. The latter were at first ignorant of what was going on. They thought the Gold Coast was a mining colony and only found out about the country's cocoa exports when they had to account for a sudden rise in the level of exports." The colonial government was surprised to discover bridges and roads, built years or decades before for the migrant cocoa farmers by Swiss contractors.

${ }^{5}$ According to The Economist (November 17, 2018, p. 54), "In 1876 Tetteh Quarshie, a blacksmith, smuggled the first cocoa beans into Ghana, hidden beneath his box of tools. He is
} 
exports were negligible before migrant cocoa farming began in 1892 and the migrant farmers introduced the new crop to the forested parts of southern Ghana, introduced new methods of production, created new forms of social organization, and in the process founded a new industry (Hill 1970). These farmers were entrepreneurs because they perceived an opportunity (Ardichvili, Cardozo and Ray 2003; Kirzner 2009, 1997) and utilized the kinship forms to create a complex labyrinth of social organization to pursue it (see Nir 2019 on "agripreneurs" in Ghana).

African farmers had been described as peasants with all the associated pejorative meanings such as lazy, cannot be incentivized, incapable of planning or simply an amorphous word of an average or ordinary household steeped into "marginalist orthodoxy" (Hill 1986, p. 70). Anthropologist Keith Hart (2005) wrote "Polly Hill was an academic who pinpointed a unique class of African farming entrepreneurs ... It would be hard to exaggerate the contrast between her Ghanaian findings and the conventional wisdom of development economists and administrators at the time and since. Her work has barely been absorbed into mainstream anthropology because it contradicts deep-seated convictions about western economic leadership and African backwardness." Her work also conflicted with the anti-capitalist orientation of later anthropology and development studies. Polly Hill's legacy continues in Ghana as young Ghanaians are encouraged to see agriculture as a business by using apps to crunch numbers (Nir, 2019). These young "agripreneurs" will repeat what their forebears did in the forests of Southern Ghana.

Hill gave voice to the rural entrepreneurs or indigenous capitalists who became the

now celebrated as a national hero; his trees, planted in the hills outside Accra, are a tourist attraction. But did cocoa make him rich? 'No,' says a guide. 'He harvested for the first time, and then he died'." 
world's biggest cocoa exporters (Austin 1997, p. ix, Hart 2005, Gregory 2006). She brought attention to the origins of cocoa industry in Ghana as one of the most remarkable example of economic growth due to innovative rural entrepreneurship the world had ever witnessed seen (see Austin 2003b, 2005, Serra 2018, but see also Austin 2003a, 2005 on coerced labor in the early period, a carry-over from the era preceding migrant cocoa farming).

\section{CROSSING AND CONTESTING BOUNDARIES OF MALE-DOMINATED DISCIPLINES}

For two years of her Smuts Readership, Polly Hill lectured on socio-economic conditions in West Africa. However, she wrote to Jack Goody, head of Cambridge's Department of Social Anthropology, on February 2, 1976 (PH 24/F3), declaring her intention not to continue those lectures. "I find the reorientation of the Department which has occurred since your appointment [succeeding Meyer Fortes in 1973], has made my position very difficult" and alluded to the tendency of students to consider any economic anthropologist not a Marxist as a "fuddy-duddy" (see e.g. Bloch, ed., 1975). She lamented being sidelined and wrote that "my long experience in West Africa was scarcely utilized" because "anything savouring of economic development goes automatically to certain people" even though she added that she was "not particularly anxious to do anything in that field."

At the end of September 1979, responding to a letter from Prof. Goody about the end of her Readership, Polly Hill expressed disgust that nine days before her Readership ended, her office was reassigned without consulting her (see PH24/F3, including intense correspondence with the department secretary and other university authorities about the loss of her office). She also expressed unhappiness that no one congratulated her on being awarded a Leverhulme 
Emeritus Fellowship to continue her work in rural South India by completing her fifth Cambridge University Press book. Only two years shy of Cambridge University's retiring age, Polly Hill became what she considered "persona non grata and instead of a golden handshake, had been given a barbed-wire handshake." She resigned her membership of the Faculty of Archaeology and Anthropology with alacrity and asked for her name to be withdrawn from Faculty lists forthwith.

Overall, her experiences as a Smuts Reader from 1973 to 1979 produced feelings of misery and of being regarded as incompetent, sidelined from graduate student supervision (interview with Macfarlane 1996). She questioned why graduate students were allocated to only two professors, one of whom she contended seldom saw his students. She consequently wrote a "To Whom It May Concern" note for the Department of Social Anthropology in which she detailed her "long experience" doing research in West Africa starting as Research Fellow rising to Senior Research Fellow at the University of Ghana from 1954 to 1964, her sabbatical as Smuts Visiting Fellow in Cambridge, and a two-year field work in rural Hausaland from 1971 to 1972. In the end, she was allotted a student to supervise whose thesis was rejected. The most striking aspect of her "To Whom It May Concern" note is that, despite her many books and articles, her doctorate and readership, she found it necessary defend her scholarly credentials.

\section{PETER BAUER: FROM SMUTS READER TO PROFESSOR AND PEER}

Polly Hill's predecessor as Smuts Reader in Commonwealth Studies (and her contemporary at Cambridge in the mid-1930s and in the Colonial Office in the late 1940s and early 1950s), Peter Bauer, went on to an LSE professorship, election as Fellow of the British Academy, the Cato Institute's inaugural Milton Friedman Prize for Advancing Liberty, an 
honorary doctorate from Cambridge, and a peerage as Lord Bauer. However, The Economist and his several festschrifts (special issues of the Cato Journal in 1987 and 2005, a three-article Cato Journal mini-symposium in 2018, a Cato Institute book in 1998, an Institute of Economic Affairs volume in 2002) repeatedly lamented his lack of academic recognition and honors, which they attributed to political prejudice against his support for market forces and neoclassical economics, with the editors of one festschrift (Dorn, Hanke and Walters, eds., 1998, p. xiv) stating that "For many years Bauer was a pariah in the field of development economics. His dissent fell on deaf ears." The Economist (May 4, 2002, p. 76) held that "His blunt lack of political correctness may have prevented Lord Bauer from sharing the Nobel prize awarded to Mr. [Amartya] Sen in 1998. The Milton Friedman prize should provide some consolation - not to mention $\$ 500,000$.” Nonetheless, his books were published by Routledge and the Duke, Cambridge, Chicago, Princeton and, most frequently, Harvard university presses, while blunt lack of political correctness did not keep the Nobel Memorial Prize from Hayek, Friedman, Schultz, Stigler, Buchanan or Becker, Bauer's peers in appreciation of the market and suspicion of state intervention.

In 1934, Peter Tamás Bauer came to Britain to study as a 19-year-old from Hungary and read economics in Cambridge, participating in Keynes's Political Economy Club. In the 1950s while Bauer was Smuts Reader and a fellow of Gonville and Caius College (a lifetime fellow after moving to his chair at LSE) he, together with Milton Friedman (on sabbatical at Cambridge from Chicago), edited the Cambridge Economic Handbooks series (founded by Keynes). Initially a student of products and markets in developing countries, whose West African Trade (1954) insisted on the applicability of mainstream neoclassical theory to understanding West African markets, Bauer became a polemicist against foreign aid, state intervention and orthodox 
development economics, which brought him exposure and standing (Tribe 2018, Bauer 1957, Bauer and Yamey 1957). Bauer disavowed several key propositions of orthodox development economics (but not the core principles of neoclassical economics) deploying "the scholarly method of careful observation, rigorous application of economic analysis, and reference to economic history" (Yamey 1987, p. 25). A fierce critic of foreign aid, Bauer argued that aid had enmeshed poor countries in their poverty, whereas market forces work well to foster economic development. He protested to the end, leading The Economist (May 4, 2002, p. 76) to state that "as Friedrich Hayek was to socialism, Peter Bauer is to foreign aid." Two days before his death, "just as he was getting the acclaim his work had long deserved," Lord Bauer told The Economist (May 11, 2002, p. 76) that "foreign aid continues to be detrimental to trading systems, continues to encourage the misallocation of local capital and skill, continues to foster government policies that impoverish rather than benefit people." Although controversial not too long ago, this view is becoming more acceptable now. For instance, Ghana Beyond Aid is the new mantra for the current Nana Akuffo Addo’s government in Ghana (see also Easterly 2016).

Polly Hill's celebration of wealth-creating innovation by indigenous entrepreneurs in West Africa and her dismissal of Marxist advice to developing countries (but not her equally blunt dismissal of development advice from outside neoclassical "experts") was in line with Peter Bauer's views, and her ten books and fifty journal articles were a body of research comparable to his. Yet she did not become a professor, prize-winner, Fellow of the British Academy, peer of the realm, or recipient of repeated laments about how little acclaim she was receiving (although in 1996, then an octogenarian, she was given an honorary doctorate by the University of London's School of Oriental and African Studies). She did not even remain employed, or manage to retain a campus office, after the end of her readership at Cambridge. 
Apart from gender, a crucial difference is that Bauer was clearly in a single discipline, the applicability of whose core theory he fervently upheld, and he had a well-defined political constituency for his message, exemplified by the Cato Institute, the Institute for Economic Affairs and Prime Minister Margaret Thatcher (who ennobled him). Hill did not identify with any single discipline and lacked a political or disciplinary constituency. Her message of the achievements of indigenous entrepreneurs fitted awkwardly with having written a Fabian Society study, having the radical economist Joan Robinson as a thesis supervisor, using the word "capitalism" in the title of one book and the subtitle of another, and being able to see the flaws of both neoclassical and Marxian economics, none of which would appeal to the Cato Institute or the Institute of Economic Affairs, who would have found what Hill wrote about African entrepreneurs congenial if they noticed it. Polly Hill's praise of entrepreneurship and grass roots initiative and aversion to top-down state planning guided by experts were greeted warmly, despite their differences with Hill on the universal applicability of neoclassical economic theory, by Peter Bauer (as Hill wrote to Joan Robinson, 12/01/61, PH 20/3) and by Theodore Schultz (Shultz to Hill, 25/09/64, PH 20/4) but this recognition, conveyed in correspondence rather than in print, was not noticed by admirers of Bauer and Schultz (Serra 2018, p. 99).

\section{SCARLETT EPSTEIN: FROM ECONOMIST TO ANTHROPOLOGIST}

Like Polly Hill, Trude Scarlett Epstein studied economics at the undergraduate level and obtained a PhD in social anthropology ${ }^{6}$ (with an economist, Ely Devons, as internal examiner and the anthropologist Raymond Firth as external examiner), from Manchester University in

\footnotetext{
${ }^{6}$ The back cover of Epstein (2005) mistakenly says her PhD was in economics. Her first academic appointment was as a research fellow in economics at the Australian National University, Canberra, where her husband was a research fellow in social anthropology.
} 
1958. Like Hill, Epstein received an undergraduate grade of 2.1 (Second Class Honors, Upper Division), but in her case that grade was considered a surprising triumph since she took her exams in hospital, dictating her answers from the bed in which she was recovering from severe burns (and at Manchester graduates with 2.1 were eligible for postgraduate scholarships). Max Gluckman, who founded Manchester's anthropology department in 1949 after directing the Rhodes-Livingstone Institute in what is now Zambia and teaching at Oxford (Kuper 1973), tried to attract an economist to conduct social anthropological studies and, invigilating one of Epstein's exams in hospital (for his own course in social anthropology), was impressed by her intellectual calibre and physical stamina. When she told her economics supervisor, Professor W. Arthur Lewis (the development economist and future Nobel laureate), what she wanted to do "he thought I was mad and that it was a waste of time. I ignored his comments and became even more absorbed in development anthropology" (Epstein 2005, p. 121). But she was not simply choosing among career paths set by senior male academics: Epstein "plucked up the courage to tell Professor Gluckman that I was much more attracted to India than to Africa. While I could see that he was disappointed he was magnanimous enough to help me to secure a Rockefeller fellowship and arranged a departmental assistantship for me" (2005, p. 122).

Epstein was interested in "action oriented" research and did not value "theoretical "ivory tower' academia" (2005, p. 122). Like Hill (1977), Epstein $(1962,1973)$ studied villagers in the south Indian state of Karnataka. As an anthropologist Epstein emphasized neutrality and immersion in the community; the elders became the most reliable informants (2005, p. 132). Nonetheless, "My training as an economist demanded that I collect a great deal of numerical data on different aspects of village life, this made me dependent on male informants as the women did not know the extent of their family's landholding, let alone the detail of cultivation costs. I much 
regretted that I had allowed the economist in me to override my interest in discovering more about village women in South India" (2005, pp. 134-35; but contrast Bina Agarwal 1994, whose disciplinary identity as an economist provided no such barrier). Similarly, Polly Hill lamented to the American anthropologist Sidney Mintz in 1962 that "As an economist, I find this type of work much more difficult than an anthropologist would. I have a) to discard everything I know b) to collect vast quantities of field notes, to realise that at stage b) I had largely missed the point, so that much of my material, as distinct from the experience of collecting it, is useless" (09/09/62, PH 22/F8, 190, quoted by Serra 2018, p. 97). Despite this residual effect of early study of economics, Scarlett Epstein became accepted as an anthropologist, named honorary fellow of the Association of Social Anthropologists and the Indian Anthropological Association, rather than being viewed as between or transcending disciplines ${ }^{7}$.

As a Jewish refugee from Vienna, Epstein lacked Hill's stellar family connections with the British academic community. After Epstein completed a diploma in economics at Ruskin College, the principal of St. Hilda's College, Oxford, told her that "though I was academically gifted, my social background would preclude my entry to any college” (Epstein 2005, p. 98). Such prejudice mattered less at Manchester: Gluckman was a South African Jew (as was his fellow Malinowski student, Meyer Fortes at Cambridge), Lewis, from St. Lucia, is still the only Nobel laureate in economics of African descent, the chair of modern history was held by Sir Lewis Namier, a Jewish immigrant from Poland.

The crucial difference between Hill's and Epstein's career path was that while Hill was a single mother from 1961, and before that was married to a registrar of school examinations,

\footnotetext{
7 However, Epstein, like Hill, was omitted from Gacs, Khan, Mclntyre and Weinberg, eds., Women Anthropologists: Selected Biographies (1988).
} 
Scarlett Epstein was married to a successful anthropologist, Bill Epstein: "In 1961 we received a letter from Max Gluckman offering us a lectureship at Manchester University. We laughed as we imagined ourselves joined at the hip, lecturing together" (Epstein 2005, p. 154). Bill took the lectureship at Manchester, while Scarlett soon after became a senior lecturer at Salford College of Advanced Technology. Five years later, he was offered a professorial fellowship in social anthropology at the Australian National University, where, after their arrival, she received a visiting fellowship (2005, pp. 163-65). Then "Bill was invited to apply for the professorship in social anthropology both at the London School of Economics and Sussex University. He made it clear that he would only accept the chair of either if I too were offered a position" so they went to Sussex in 1972, he as professor of social anthropology, she as a research professor in the Institute of Development Studies (2005, pp. 166-67). The Institute of Development Studies demurred at full reappointment after Scarlett Epstein's five-year term as research professor, offering a shorter limited-term appointment because of her supposedly insufficient publication (as she recounted in her thirteenth book), but, surprising her IDS colleagues, she was able to move to Sussex's School of African and Asian Studies (AFRAS), where Bill worked: "I was on tenterhooks while Bill worked out the details. Within a few days he managed to get the dean of AFRAS to offer me a research professorship on condition that I came with [external] research funds" that shehad been awarded while in IDS (Epstein 2005, p. 172-73). So, Scarlett Epstein's career does not show that gender could not have been a barrier to Polly Hill's academic advancement, but only that the gender barrier could be overcome by spousal appointments. The Epsteins always kept their research separate: "we knew from the field-work experience of other married social anthropologists that joint studies can put a strain on a relationship" (2005, p. 150), so there was no issue of maintaining her identity as a researcher. Scarlett Epstein was, like Polly 
Hill, a most productive scholar, but her academic employment depended critically on her husband's status.

\section{CONCLUSION}

Polly Hill began as an economist, trained at Cambridge in the 1930s and inspired by her uncle Maynard Keynes, but experience in Ghana, and later in Nigeria and India, moved her from mainstream economics to advocate "field economics" or "indigenous economics," gaining a doctorate in social anthropology, fellowships in social anthropology and African studies, and a readership in Commonwealth studies, but no secure position in any discipline or interdisciplinary field. Her field research, especially that on the migrant cocoa farmers of southern Ghana, revealed the contribution of indigenous entrepreneurs to economic development, work that should be highly relevant for development economics, development studies, economic and social anthropology, African studies, entrepreneurship studies and, because of her attention to the role of women as entrepreneurs, to women's studies. With a few notable exceptions such as Gareth Austin (1997, 2003b, 2005) and Keith Hart (Hann and Hart 2016), Polly Hill has not had the influence in any one of these disciplinary and interdisciplinary fields that the volume and importance of her research might warrant because, except for entrepreneurship studies, her work cannot be fitted neatly into any one of these categories. Development economics, as represented by Kaushik Basu's Analytical Development Economics (1997), ignores Polly Hill's critique of the applicability of mainstream neoclassical economic theory to developing countries, while development studies, as represented by The Companion to Development Studies (Desai and Potter, eds., 2008), extends no welcome to a celebration of West African rural capitalism or any other capitalism and only limited welcome to non-Marxist economists, standpoints widely shared 
in African studies, women's studies and to some extent anthropology. Polly Hill exited economics to the point she is overlooked in the leading feminist study of women's contributions to development economics (Rodgers and Cooley 1999) but, unlike Scarlett Epstein, lacked the influential male backing then needed to be fully accepted into anthropology. Unlike Peter Bauer, Polly Hill did not find a powerful disciplinary or political constituency for her celebration of grass-roots initiative and criticism of top-down planning. Her blunt critiques of Western and Marxist "experts," of formalists such as Bliss and Stern (1992) and of substantivists such as Bohannan and Dalton (1962), advanced knowledge and understanding without winning friends and allies. Nonetheless, despite the frustrations and challenges of her career resulting from her insecure and ambiguous disciplinary status, Polly Hill achieved insight into grass-roots entrepreneurial innovation and wealth creation in developing countries by integrating research methodologies that bridged and trampled upon disciplinary boundaries.

\section{ARCHIVAL COLLECTION}

Polly Hill Papers, Melville J. Herskovits Library of African Studies, Northwestern University, Evanston, IL (see Barbara K. Hammond and Musifiky Mwanasali 1994, and subsequent online revisions). Cited as $\mathrm{PH}$.

A bibliography of Polly Hill's published writings appeared in Cambridge Anthropology 26, 1 (2006).

\section{REFERENCES}

Agarwal, Bina. 1994. A Field of One's Own: Gender and Land Rights in South Asia. Cambridge, UK: Cambridge University Press. 
Ardichvili, Alexander, Cardozo, Richard, and Ray, Sourav 2003. "A Theory of Entrepreneurial Opportunity Identification and Development," Journal of Business Venturing, 18, 1: 105123.

Aslanbegui, Nahid, and Guy Oakes. 2009. The Provocative Joan Robinson: The Making of a Cambridge Economist. Durham, NC: Duke University Press.

Austin, Gareth. 1997. "Introduction" to Polly Hill, The Migrant Cocoa-Farmers of Southern Ghana, Classics in African Anthropology edition, Oxford: James Currey and International African Institute, pp. ix-xxviii.

Austin, Gareth. 2003a. Human Pawning in Asante, 1820-1950: Markets and Coercion, Gender and Cocoa. Trenton, NJ: Africa World Press.

Austen, Gareth. 2003b. "African Rural Capitalism, Cocoa Farming and Economic Growth in Colonial Ghana," in Toyin Falola, ed., Ghana in Africa and the World: Essays in Honor of Adu Boahen, Trenton, NJ: Africa World Press, pp. 437-53.

Austen, Gareth. 2005. Labor, Land and Capital in Ghana: From Slavery to Free Labor in Asante, 1807-1956. Rochester, NY: University of Rochester Press.

Austen, Gareth. 2011. “A. G. Hopkins, West Africa and Economic History”, in Toyin Falola and Emily Brownell, eds., Africa, Empire and Globalization: Essays in Honor of A. G. Hopkins. Durham, NC: Carolina Academic Press.

Bardhan, Pranab, ed. 1989. Conversations between Anthropologists and Economists: Methodological Issues in Measuring Economic Change in Rural India. Delhi and New York: Oxford University Press.

Bardhan, Pranab, and Isha Ray, eds. 2008. The Contested Commons: Conversations between Economists and Anthropologists. Malden, MA: Blackwell. 
Basu, Kaushik. 1997. Analytical Development Economics: The Less Developed Economy Revisited. Cambridge, MA: MIT Press.

Bauer, Peter. 1954. West African Trade: A Study of Competition, Oligopoly and Monopoly in a Changing Economy. Cambridge, UK: Cambridge University Press.

Bauer, Peter. 1957. Economic Analysis and Policy in Underdeveloped Countries. Durham, NC: Duke University Press.

Bauer, Peter, and Basil Yamey. 1957. The Economics of Underdeveloped Countries. Chicago: University of Chicago Press, Cambridge Economic Handbooks.

Bharadwaj, Krishna. 1974. Production Conditions in Indian Agriculture as Reflected in the Farm Management Studies. Cambridge, UK: Cambridge University Press.

Bharadwaj. Krishna. 1989. Themes in Value and Distribution: Classical Theory Reappraised. London: Unwin Hyman.

Bliss, Christopher, and Nicholas Stern. 1982. Palanpur: The Economy of an Indian Village. Oxford: Clarendon Press.

Bloch, Maurice, ed. 1975. Marxist Analyses and Social Anthropology. London: Malaby Press.

Bohannon, Paul, and George Dalton, eds. 1962. Markets in Africa. Evanston, IL: Northwestern University Press.

Cook, S., and M. W. Young. 2016. "Malinowski, Herskovits and the Controversy over Economics in Anthropology," History of Political Economy 48, 4: 657-79.

Dalton, George. 1968. "Economics, Economic Development and Economic Anthropology," Journal of Economic Issues 2, 2: 173-186.

Desai, Vandana, and Robert Potter, eds. 2008. The Companion to Development Studies, 2nd ed. London: Hodder. 
Dimand, Robert W., and Kojo Saffu. 2017. "Polly Hill (1914-2005)," in Robert A. Cord., ed., The Palgrave Companion to Cambridge Economics, Vol. 2, London, Basingstoke and New York: Palgrave Macmillan, pp. 857-870.

Dorn, James, Steve Hanke, and Alan Walters, eds. 1998. The Revolution in Development Economics. Washington, DC: Cato Institute.

Easterly, William. 2016. The Economics of International Development: Foreign Aid versus Freedom for the World's Poor. London: Institute of Economic Affairs, IEA Hayek Memorial Lecture.

Economist, The. 2002. “A Voice for the Poor: As Friedrich Hayek was to socialism, Peter Bauer is to foreign aid," May 4, p. 76; "Peter Bauer," May 11, p. 76.

Economist, The. 2018. "Sweet dreams: Cocoa processing in not a golden ticket for west Africa," November 17, p. 54.

Epstein, T. Scarlett. 1962. Economic Development and Social Change in South Asia. Manchester: Manchester University Press.

Epstein, T. Scarlett. 1973. South India: Yesterday, Today and Tomorrow: Mysore Villages Revisited. London: Macmillan.

Epstein, T. Scarlett. 2005. Swimming Upstream: A Jewish Refugee from Vienna. London and Portland, OR: Vallentine Mitchell.

Firth, Raymond, ed. 1967. Themes in Economic Anthropology. London: Tavistock.

Gacs, Ute, Aisha Khan, Jerrie McIntyre, and Ruth Weinberg, eds. 1988. Women Anthropologists: Selected Biographies. Westport, CT: Greenwood Press.

Goody, Jack. 1995. The Expansive Moment: Anthropology in Britain and in Africa, 1918-1970. Cambridge, UK: Cambridge University Press. 
Gregory, C. A. 2006. "Polly Hill (1914-2005)," in D. A. Clark, ed., The Elgar Companion to Development Studies, Cheltenham, UK, and Northampton, MA: Edward Elgar, pp. 22326.

Hammond, Barbara, and Musifiky Mwanasali. 1994. Guide to the Polly Hill Papers. Evanston, IL: Melville J. Herskovits Library of African Studies, Northwestern University (later updates online).

Hann, Chris, and Hart, Keith. 2016. Economic Anthropology: History, Ethnography, Critique. Cambridge, UK: Polity Press.

Harcourt, G. C. 1993-94. "Krishna Bharadwaj, August 21, 1935-March 8, 1992: A Memoir," Journal of Post Keynesian Economics 16, 2: 299-311.

Hart, Keith, 2005. "Polly Hill: An Academic who Pinpointed a Unique Class of African Farming Entrepreneurs," The Guardian, 26 August, p. 31.

Hill, A. V. 1960. The Ethical Dilemma of Science and Other Writings. New York: Rockefeller Institute Press in association with Oxford University Press; London: Scientific Book Guild, 1962.

Hill, Polly. 1940. The Unemployment Services: A Report Prepared for the Fabian Society. London: Routledge.

Hill, Polly. 1956. The Gold Coast Cocoa Farmer: A Preliminary Survey. London: Oxford University Press.

Hill, Polly. 1962. “Some Characteristics of Indigenous West African Enterprise, ” Economic Bulletin of Ghana 6, 1: 3-14.

Hill, Polly. 1963. The Migrant Cocoa Farmers of Southern Ghana: A Study in Rural Capitalism. Cambridge, UK: Cambridge University Press. 
Hill, Polly. 1970. Studies in Rural Capitalism in West Africa. Cambridge, UK: Cambridge University Press.

Hill, Polly. 1972. Rural Hausa: A Village and a Setting. Cambridge, UK: Cambridge University Press.

Hill, Polly. 1977. Population, Prosperity, and Poverty: Rural Kano, 1900 and 1970. Cambridge, UK: Cambridge University Press.

Hill, Polly. 1978. “Problems with A. G. Hopkins' Economic History of West Africa, ” African Economic History 6:127-33.

Hill, Polly. 1982. Dry Grain Farming Families: Hausaland (Nigeria) and Karnataka (India) Compared. Cambridge, UK: Cambridge University Press.

Hill, Polly. 1986. Development Economics on Trial: The Anthropological Case for a Prosecution. Cambridge, UK: Cambridge University Press.

Hill, Polly. 1992. Fante Villages in Southern Ghana: Migration and the 'Hopelessness' of Food Farming. Cambridge, UK: African Studies Centre, University of Cambridge.

Hill, Polly, and Richard Keynes, eds. 1989. Lydia and Maynard: The Letters between Lydia Lopokova and John Maynard Keynes. London: André Deutsch.

Hopkins, A. G. 1973. An Economic History of West Africa. London: Longman.

Hopkins, A. G. 1978. “An Economic History of West Africa: A Further Comment,” African Economic History 6: 139-44.

Jerven, Morten. 2013. Poor Numbers: How We are Misled by African Development Statistics and What to do About It. Ithaca, NY: Cornell University Press.

Jerven, Morten. 2015. Africa: Why Economists Get It Wrong. London: Zed Books.

Kerr, Prue. 2017. "Joan Violet Robinson (1903-1983)," in Robert Cord, ed., The Palgrave 
Companion to Cambridge Economics, London and Basingstoke: Palgrave Macmillan, pp. 673-704.

Kirzner, Israel. 1997. "Entrepreneurial Discovery and the Competitive Market Process: An Austrian Approach,” Journal of Economic Literature 35, 1: 60-85.

Kirzner, Israel. 2009. “The Alert and Creative Entrepreneur: A Clarification,” Small Business Economics 32, 2: 145-53.

Knight, Frank. 1941. “Anthropology and Economics,” Journal of Political Economy 49, 2: 24768, with rejoinder by Melville Herskovits, pp. 269-78, both reprinted in Melville Herskovits, Economic Anthropology, New York: Knopf, 1952.

Kuper, Adam. 1973. Anthropologists and Anthropology: The British School 1922-1972. Hardmondsworth, UK: Penguin.

Lodewijks, John. 1994. “Anthropologists and Economists: Conflict or Cooperation?” Journal of Economic Methodology 1, 1: 81-104.

Macfarlane, Alan. 1996. "Interview with Polly Hill,” 20 July. Available at http://www.alanmacfarlane.com/ancestors/Hill.html and https://www.sms.cam.ac.uk/media/1121408

Mills, David. 2009. "Hill, Mary Eglantyne [Polly\} (1914-2005)," Oxford Dictionary of National Biography online, article 96631.

Nir, Sarah Maslin. 2019. “In Africa, Taking Up Farming to Change Attitudes,” New York Times International Weekly, June 8, p. 4.

Ogburn, William, and Alexander Goldenweiser, eds. 1927. The Social Sciences and Their Interrelations. Boston: Houghton Mifflin.

Perham, Margery. 1937. Native Administration in Nigeria. London: Oxford University Press. 
Perham, Margery, ed. 1946. The Native Economies of Nigeria, vol. 1. London: Faber.

Perham, Margery. 1960. Lugard: The Years of Authority, 1898-1945. London: Collins.

Posner, Richard. 1980. “Anthropology and Economics," Journal of Political Economy 88, 3:60816.

Robertson, Claire. 1984. Sharing the Same Bowl: A Socioeconomic History of Women and Class in Accra, Ghana. Bloomington, IN: Indiana University Press.

Robinson, Joan. 1979. Aspects of Development and Underdevelopment. Cambridge, UK: Cambridge University Press, Modern Cambridge Economics.

Rodgers, Yana van der Meulen, and Jane C. Cooley. 1999. "Outstanding Female Economists in the Analysis and Practice of Development Economics," World Development 27, 8: 1397 1411.

Schumpeter, Joseph. [1911] 1934. The Theory of Economic Development. Cambridge, MA: Harvard University Press.

Saffu, Kojo, and A. Anum. 2005. "Growth Strategies of Ghanaian Female Entrepreneurs," Conference Proceedings of 6th International Academy of African Business and Development, Dar-es-Salaam, Best Paper Award in Entrepreneurship.

Serra, Gerardo. 2018. "Pleas for Fieldwork: Polly Hill on Observation and Induction, 19661982," Research in the History of Economic Thought and Methodology 36B: 93-108.

Simms, Ruth. 1981. "The African Woman as Entrepreneur: Problems and Perspectives on their Roles,” in F. C. Steady, ed., The Black Woman Cross-Culturally, Cambridge, MA: Schenkman, pp. 141-68.

Tribe, Keith. 2018. “The Colonial Office and British Development Economics, 1940-60," in M. Alacevich and M. Boianovsky, eds., The Political Economy of Development Economics: 
A Historical Perspective, Annual Supplement to History of Political Economy, Durham, NC: Duke University Press, pp. 97-113.

Yamey, Basil. 1987. "Peter Bauer: Economist and Scholar," Cato Journal 1, 1: 21-27. 